\title{
The Use of Biochar for the Production of Organic Fertilizers
}

\author{
Wojciech Czekała ${ }^{*}$, Aleksandra Jeżowska', Dawid Chełkowski' \\ 1 Institute of Biosystems Engineering, Poznan University of Life Sciences, Wojska Polskiego 28, 60-637 Poznan, \\ Poland \\ * Corresponding author's e-mail: wojciech@up.poznan.pl
}

\begin{abstract}
The fertilizer management is one of the greatest challenges of agriculture in the $21^{\text {st }}$ century. The growing demand for food, along with the similar amount of arable land, creates the necessity of increasing the crop yields in a given area. Due to the fact that the production and use of mineral fertilizers often influence the environment in a negative way, for many years more attention has been paid to natural and organic fertilizers. Their advantage is the transfer of not only organic matter but also nutrients to the soil. In connection with the structural changes in agriculture, the production of natural fertilizers, especially manure decreases, but at the same time, the production of other organic fertilizers, e.g. composts or biochar increases. The aim of the work was to present the possibility of using biochar in the production of organic fertilizers. Moreover, the project concept for obtaining an organic fertilizer containing biochar and its application in the processes of biological transformation of waste was presented.
\end{abstract}

Keywords: biochar, fertilizer, agricultural land, environmental protection, waste management.

\section{INTRODUCTION}

The growing demand for food determines the need to increase the yield of crops, vegetables or fruit from the unit of land [Keating et al., 2014]. The most popular and also effective treatment to achieve the above-mentioned goal is. i.a. fertilization [Fageria et al., 2008]. However, one cannot ignore the breeding aspect associated with new, high-yield varieties of individual plant species. Still, fertilization is an important factor in shaping the growth and yield of crops resulting, i.a., from the possibility of providing nutrients for the plant development in appropriate amounts, optimal periods and forms of bioavailability.

Mineral fertilization, along with agrotechnical treatments, also affect the soil properties, not always in a favorable way, which often seen in monoculture crops. This applies, above all, to soil reaction and humus, which fundamentally shapes the physical, chemical and biological properties of the soil [Bot and Benites, 2005]. Thus, it has an indirect effect on yielding plants. This influence is also due to the limitation of adverse effects of mineral fertilizer (mainly nitro- gen fertilizer), e.g. on soil acidification. It has already been proven [Flaig, 1968] that using combined nitrogenous and organic fertilizers, the yield of plants is higher than without their use. Further studies have shown that this influence also results from the plant uptake of active substances from humus that directly affect the plant metabolism, such as stimulation of germination, plant growth, nutrient uptake or protein synthesis and activity [Ouni et al. 2014]. The results of many years of research indicate that while using combined mineral and organic fertilization, an increase in yield was observed by $10 \%$ on sandy soils and up to $6 \%$ on clay soils [Scholz 1978, Beuke 2006]. In addition, such treatment in the scope of many years can be a way of achieving stabilization of plant yielding. This means that in an unfavorable period for plant growth, the soil collects not only the valuable ingredients, but thanks to the greater abundance in humus, there is a larger amount of accumulated water. Moreover, it is important to increase the abundance of soils in carbon and nitrogen, which are the indicators of soil fertility [Körschens 2013]. For this reason, agricultural organic waste has 
been used for many years as fertilizers, which also solves the problem of their storage and uncontrolled decomposition [Czekała et al., 2017]. A beneficial effect of reducing nitrogen emissions from arable fields is also significant [Brockmann et al., 2018]. Natural and organic fertilizers are also the sources of essential nutrients for plants, such as: nitrogen, phosphorus, potassium, calcium, magnesium and sulfur, as well as microelements.

At present, is possible to observe the activities aimed at increasing the amount of crops per hectare, as well as proper management of waste from the agri-food industry [Czekała, 2018; Ekielski et al., 2017]. The simultaneous use of mineral, natural and organic fertilizers (including manure, compost or slurry) for fertilizing purposes solves the problem of storage and reduces the need for disposing mineral fertilizers. In addition to the typical organic fertilizers, other sources of substrates are also being searched for the production of new organic fertilizers. One such source is biochar.

The aim of the following work was to present the possibility of using biochar for the production of organic fertilizers and the design concept for obtaining such fertilizer. At the same time, the obtained fertilizer will be used in fertilization and in the processes of biological transformation of waste.

\section{ORGANIC FERTILIZERS USED IN AGRICULTURE}

In recent years, there has been an increase in the number of legal regulations pertaining to the improvement of both soil properties and quality. Special attention is being paid to reducing the use of mineral fertilizers and plant health products. One of the rational solutions for the above-mentioned problems is the use of organic fertilizers, including those with additives, such as biochar [Malińska, 2012]. This is due to the fact that the Polish soils are poor in humus, which results in lowering the crop yield. Organic fertilizers are the fertilizers that help creating soil humus through the appropriate content of organic substances. According to the definition of the nutrients presented by Arnon and Stout in 1939, the plant cannot complete its growth cycle in the absence of any of the nutrients, as none of these substances can be replaced with one another [Gorlach and Mazur, 2002].
The largest costs in farms worldwide are associated with the fertilizers and plant protection products. In order to limit their negative impact on the farm environment, greater attention should be paid to the proper management of fertilization process. Therefore, alternative solutions are sought for supplying appropriate nutrients to crop plants. Organic fertilizers, such as composts, straw or digestate from biogas plants can be sources of this.

The most popular organic fertilizer is compost. As a result of composting the substrates rich in organic matter, a new fertilizer with high fertilizing properties, especially high organic matter content is created (Wojcieszak et al., 2015). The advantages of the process mainly include simplicity of technologies and possibility of implementation on every farm. Apart from compost, straw is a popular organic fertilizer. The application absence of bedding system and reduction of animal population in Poland resulted in a reduced demand for straw as bedding, which increased its use for fertilizing purposes. Straw is the source of organic matter, but also nutrients to a lesser extent. In recent years, straw has been used for the production of solid biofuels being a competition for the substrate in question. However, a product which has only recently been used in fertilization is the digestate from biogas plant that takes into account all compounds undistributed in the process of methane fermentation, both organic and mineral. Depending on their quantity, the digestate may be treated as an organic or organic-mineral fertilizer after obtaining relevant documents. A common solution is the separation of the digestate in the biogas plant and direct fertilization, or the production of compost from the solid fraction resulting from separation. Apart from compost or the solid fraction of digestate, dry fertilizers and granule fertilizers are also often mentioned among the organic fertilizers [Ketonen, 1992].

A research on the utilization, quality and nutrient content in organic fertilizers produced from the agricultural waste was carried out, e.g. by Arkhipchenko (2005). In the experiment, composted poultry droppings and poultry manure after the methane fermentation were used. Positive effects on the plant growth and on the inhibition of phytopathogenic growth of microflora in soil were observed. The disadvantage of direct application of manure is the probability of introducing significant amounts of seeds into the soil. Therefore, it is extremely important to process 
these fertilizers properly before applying to the soil [Arkhipchenko et al., 2005]. All components, the compost obtained on the basis of animal manure together with various organic fertilizers and proper straw management belong to the group of products applied to soil, which have a large impact on fertility in ecological farming systems [Hasegawa et al., 2005]. The studies conducted by Jannoura (2014) proved that the use of horse manure and compost (green waste) increased the content of dry matter in peas, contributed to faster photosynthesis rate, improved $\mathrm{N}_{2}$ binding and $\mathrm{N}$ accumulation [Jannoura et al., 2014]. In different studies [Koszel and Lorencowicz, 2015] an increase of macroelements in alfalfa leaves was observed using digestate from biogas plants for the plant fertilization purposes.

Biochar has become a type of material that systematically gains popularity in agriculture and environmental protection. It is used, among others, as an addition to slurry or in the production of compost. The use of biochar enables to enrich the properties of fertilizer, which affect the quality of soils. The sorption capabilities of pollutants from soil and water play a valuable role in environmental protection. The biochar applied into the soil with organic carbon and a number of macroand micronutrients $(\mathrm{N}, \mathrm{P}, \mathrm{K}, \mathrm{Mg}, \mathrm{Ca})$ constitute a valuable source of ingredients for plants and soil microflora development. [Malińska, 2012; Malińska, 2015].

\section{BIOCHAR - PRODUCTION AND PROPERTIES}

Biochar is one of the products of biomass pyrolysis, which has been known for thousands of years in the form of charcoal [Weber and 2018; Cha et al., 2016; Yu et al., 2011; Dias et al., 2010]. Due to its properties and the possibility of multiple uses in many areas, the interest in this material is growing taking into consideration agricultural, environmental protection or energy aspects. On the basis of numerous publications, it can be defined in various ways, as a solid material with a high carbon content, a product of slow pyrolysis and as a material formed by the thermochemical decomposition of biomass. The pyrolysis process can be described as a thermal decomposition of organic matter with no or very limited access of oxygen. The result of this process involves solid products (including biochar), liquid (bio-oil) and gas (syngas). It is distinguished by fast, flash, slow (carbonization) pyrolysis as well as gasification (Table 1) [Verheijenet et al., 2009; Maiti et al., 2005].

An important fact is that biochar can be produced from a wide range of organic materials. These include agricultural biomass, sewage sediment, forest waste, energy crops and residues from agro-food processing [Malińska 2012]. Biochar is most often used to improve the soil quality [Lehmann et al., 2011] due to its extensive properties; that is why more and more attention is focused on the use of biochar both in agriculture and environmental protection.

\section{USE OF BIOCHAR IN AGRICULTURE AND WASTE MANAGEMENT}

Since Poland's entry into the EU, an emphasis has been put on following the sustainable economy policy. Environmental protection and agriculture have become the areas, which require changes. As for the issue regarding agriculture, the attention is paid to the economy and management of natural and organic fertilizers. When it comes to the application of fertilizers of both groups, it is very important to follow the guidelines contained in the Act of 10 July 2007 on fertilizers and fertilization [Journal of Laws, 2007, no. 147, item 1033]. Pursuant to the afore-mentioned Act, organic fertilizers include all the fertilizers produced from organic substances or their mixtures,

Table 1. Percentage content of pyrolysis products depending on the type of process [Verheijen 2009]

\begin{tabular}{|c|c|c|c|c|}
\hline Type & Conditions & Liquid fraction & Biochar & Syngas \\
\hline Fast pyrolysis & $\begin{array}{l}\text { Moderate temperature, } \sim 500{ }^{\circ} \mathrm{C} \text {, short residence time } \\
\text { of hot steam of } \sim 1 \mathrm{~s}\end{array}$ & $75 \%$ & $12 \%$ & $13 \%$ \\
\hline Flash pyrolysis & $\begin{array}{l}\text { Moderate temperature, } \sim 500{ }^{\circ} \mathrm{C} \text {, short residence time } \\
\text { of hot steam of } \sim 10-20 \mathrm{~s}\end{array}$ & $50 \%$ & $20 \%$ & $30 \%$ \\
\hline $\begin{array}{l}\text { Slow pyrolysis } \\
\text { (carbonization) }\end{array}$ & $\begin{array}{l}\text { Low temperature } \sim 400^{\circ} \mathrm{C} \text {, very long residence time } \\
\text { of solid substances }\end{array}$ & $30 \%$ & $35 \%$ & $35 \%$ \\
\hline Gasification & High temperature $\sim 800^{\circ} \mathrm{C}$, long residence time of steam & $5 \%$ & $10 \%$ & $85 \%$ \\
\hline
\end{tabular}


including composts. Only the fertilizers that have been admitted to trading, pursuant to Art. 3 par. 1 and 2, art. 5 and Regulation No. 2003/2003 are acceptable. The physical, physicochemical and chemical analyses of fertilizers, as well as soils, are carried out by District Chemical and Agricultural Stations having appropriate certificates. Taking the analyses of these fertilizers into consideration, one can choose the appropriate dosage of selected organic fertilizers, so as to obtain the most beneficial effect for soil. Due to numerous positive physical and chemical properties, biochar has become a subject of numerous scientific and implementation studies in recent years. The currently obtained results prove that biochar is characterized by diverse properties, caused primarily by the biomass used and the parameters of the pyrolysis process. Biochar may contain from 50 to $90 \%$ of organic carbon, from 1 to $15 \%$ of moisture content, from 0 to $40 \%$ of volatile substances and from 0.5 to $5 \%$ of mineral matter, characterized by neutral or alkaline reaction. Biochar has also variable phosphorus and potassium content, resulting from the material used, which for phosphorus (P) range from 2.7 to 480 $\mathrm{g} \cdot \mathrm{kg}^{-1}$ and for potassium (K) from 1.0 to $58 \mathrm{~g} \cdot \mathrm{kg}^{-1}$ [Malińska 2012, Malińska et al., 2014; Beesley et al., 2011; Dias et al., 2010].

Due to its sorption properties, biochar has a very wide range of applications, including fertilization [Steinbeiss et al., 2009], composting [Czekała et al., 2016; Dias et al., 2010], water and wastewater treatment [Mohan and Pittman, 2007], environmental protection and reclamation [Yu et al., 2011; Beesley et al., 2011].

In a country where the number of inhabitants is still growing, it is important to use every possible areas for cultivation. For two years, in the north of China, a field study was conducted under rainy conditions using biochar as an organic fertilizer. Previously, in this area the fertilization was characterized by a high $\mathrm{N}$ and low $\mathrm{P}$ level. Thanks to the use of biochar on corn plantation, a significant increase in yields and a lower emission of $\mathrm{N}_{2} \mathrm{O}$ were observed. In the experiment, biochar was used at doses of 0,20 and $40 \mathrm{Mg} \cdot \mathrm{ha}^{-1}$, which can be considered a relatively small amount. Due to sustainable fertilization with the addition of biochar, the yield of corn during the first year increased by $16.77 \%$ (dose $20 \mathrm{Mg} \cdot \mathrm{ha}^{-1}$ ) and by $11.9 \%$ (dose $40 \mathrm{Mg} \cdot \mathrm{ha}^{-1}$ ). During the next year of research, a $20 \mathrm{Mg} \cdot \mathrm{ha}^{-1}$ dose increased by $19.8 \%$ and a $35.4 \%$ dose by $40 \mathrm{Mg} \cdot \mathrm{ha}^{-1}$. An important aspect of the biochar was the reduction of $\mathrm{N}_{2} \mathrm{O}$ emission by half as compared to NPK. The obtained data also showed the possibility of reducing the consumption of mineral fertilizers, which are used on large corn plantations in large quantities - up to $400 \mathrm{~kg} \mathrm{~N} \cdot \mathrm{ha}^{-1}$ per year [Zhang et al., 2016]. The analysis of the subject literature shows that the most frequently mentioned advantage of biochar soil application is the increase in plant yields [Yu el al., 2011; Beesley et al., 2011; Verheijen et al., 2009].

The adsorbing properties of biochar are also utilized in water and wastewater treatment. This is indicated, among others, by the research on the capture of such ions as $\mathrm{As}^{3+}, \mathrm{Cd}^{2+}, \mathrm{Pb}^{2+}[\mathrm{Mo}-$ han and Pittman, 2007]. From the environmental point of view, an important feature of biochar is its effect on reducing $\mathrm{N}_{2} \mathrm{O}$ emissions to the atmosphere. This is confirmed, among others, by the research conducted on corn plantations at the Scientific and Research Center of the University of Illinois in Urbana, USA. The crop was divided into 4 blocks: control, biochar $\left(100 \mathrm{Mg} \cdot \mathrm{ha}^{-1}\right)$, nitrogen fertilization $\left(269 \mathrm{~kg} \mathrm{~N} \cdot \mathrm{ha}^{-1}\right)$ and biochar + nitrogen $\left(100 \mathrm{Mg} \cdot \mathrm{ha}^{-1}+269 \mathrm{~kg} \mathrm{~N} \cdot \mathrm{ha}^{-1}\right)$. It has been shown that biochar has reduced the $\mathrm{N}_{2} \mathrm{O}$ emission of soil on the areas with high $\mathrm{N}$ doses, to the levels close to the control group (no addition of nitrogen fertilizers and biochar) [Edwards et al., 2018]. In other multiannual studies, the example of winter wheat showed a positive effect of organic fertilizers on the increase of soil microbial biomass content (SMBC) as well as soil microbial biomass nitrogen (SMBN) [Li et al., 2018].

Currently, research is being conducted on the use of biochar for the reclamation of contaminated or degraded area, as it is very widely applied in remediation, reclamation and renewal of contaminated soils. The biochar action consists of, among others, dispersing pesticides and herbicides in soil by increasing the sorption capacity of the soil. The issue is more complex when taking into account pesticides, thus the use of biochar must be carefully considered, because the doses of pesticides do not show a weakened action [Yu et al., 2011]. The factors that threaten the plant growth are also soil salinity and sulfur content. This problem is of particular importance in the dry regions of the world, where both factors significantly influence the cultivation of soils. It is estimated that the total soil area affected by this problem amounts to about 1 billion ha [Tóth et al., 2008], with an increasing trend caused by in- 
adequate water management and climate change. Although most studies on the issue were carried out for a short period of time, the biochar proved to improve the plant growth as well as physical, chemical and biological properties of extremely saline soils. Other problems that can arise during fertilization of saline soils concern the production and transport costs of biochar [Saifullah et al., 2018].

The application of biochar with regard to the economic and eco-friendly aspects seems to take place in the remediation of phosphorus in the aquatic environment. This is related not only to the issue of eutrophication of waters, but to a lesser extent to the scientific interest of biochar use in this field [Vikrant et al., 2018].

The comprehensive use of biochar properties is also applicable in wastewater treatment plants by adding biochar to sewage sludge. Sewage sludge is a waste with high content of organic matter, phosphorus, nitrogen and micronutrients, which enables to use it for fertilization purposes. However, due to the presence of toxic substances in sediments, such as heavy metals and organic microorganisms (e.g. WWA, PCBs, PCDDs, PCDD / Fs, Antibiotic et al.), there is a risk of soil contamination. In one of the experiments [Kończak and, Oleszczuk, 2018] fertilization effect was examined with the use of sewage sludge $\left(10 \mathrm{tdw} \cdot \mathrm{ha}^{-1}\right)$ and sewage sludge $\left(10 \mathrm{tdw} \cdot \mathrm{ha}^{-1}\right)$ with the addition of biochar $(2.5,5$ or $10 \%$ in relation to the sewage sludge mass). The toxicity of unmodified and modified soil and sewage sludge was tested, which showed that the addition of biochar in sewage sludge and soil reduced leaching of nutrients, which resulted in their longer maintenance in soil and availability for plants. The toxicity of sediments was also lower. After 18 months of research, a beneficial effect on stimulation of Folsomia candida arthropods was found; however, it related to the dosage of biochar. At the lowest dose of biochar (2.5\%), their reproduction increased by $75 \%$, at $5 \%$ dose, it increased by another $15 \%$, and at $10 \%$ of biochar by $13 \%$. In another experiment, when using biochar as an additive to sewage sludge, faster root growth was observed in Lepidium sativum (Phytotoxkit F). The increase was observed in the fields with sewage sludge and biochar by $19.6 \%$ at a biochar dose of $2.5 \%, 17.0 \%$ at $5 \%$ and $27.4 \%$ at a dose of $10 \%$ compared to the fertilization only with sewage sludge [Oleszczuk et al., 2012]. Other beneficial effects of biochar were also demonstrated in the corn experiment, with its faster growth and leaf number [Gwenzi et al., 2016].

As mentioned earlier, both biochar and organic fertilizers with its addition can positively affect the soil properties, as well as the plant growth and development. Therefore, research was undertaken on the use of biochar in environmental protection, and more specifically in waste management. As for the biogas production, biochar can be used at various stages of the process; first of all, as an addition to fodder or bedding at the stage of animal husbandry, to limit the greenhouse gas emissions. Biochar can be used to properly prepare substrates for fermentation, by removing excess ammonia $\left(\mathrm{NH}_{3}\right)$ and ammonium ions $\left(\mathrm{NH}^{4+}\right)$. Moreover, it has a positive effect on the biogas purification process, thanks to the removal of sulfur compounds. The solid residue fraction of the fermentation process also meets the conditions of becoming a substrate for biochar production, which can be used for energy or fertilizer purposes as a soil improver [Malińska and Dach, 2015].

A number of studies indicate the positive use of biochar in the methane fermentation process. In the following process, the absorbing properties of biochar were used, which inhibit substances, e.g. ammonia or limonene. The presence of biochar in the fermentation process contributes to, inter alia, faster degradation of organic matter and leveling of $\mathrm{pH}$ value [Luz et al., 2018; Mumme et al., 2014].

Due to the large amounts of wastes such as biodegradable municipal waste, agricultural waste from forestry and food industry, the research on the effect of the addition of biochar on optimizing the composting process has been initiated. In the presence of biochar, greenhouse gas emissions (especially $\mathrm{CH}_{4}, \mathrm{~N}_{2} \mathrm{O}$ ), as well as nitrogen, are reduced in the proper compost. What is important, it can also be used for purification of air from the process gases [Malińska and Dach, 2014].

Thanks to its sorption properties, the biochar is increasingly used in the composting process and its role is mainly related to the reduction of gas emissions and process temperature [Czekała et al., 2016; Malińska et al., 2014]. The biochar potential in the composting process is also related to its structure-forming properties, which can affect the degradation of organic matter and the degree of compost humification [Dias et al., 2010]. For the moment, the research results indicate the need to continue the study, especially in the meth- 
ane fermentation and composting process. Both processes provide the products of fertilizing nature, which directly affect not only soil properties, but also the increase in the yield of plants. [Czekała et al., 2017].

\section{USE OF BIOCHAR IN THE PRODUCTION OF ORGANIC FERTILIZERS IN PELLETS}

As part of the "Research on the Innovative Form of Organic Fertilisers" project implementation, an organic fertilizer containing biochar in the form of pellets was obtained. The samples tested with the addition $10 \%$ and $12 \%$ of biochar with a diameter of $4 \mathrm{~mm}$, were regarded as the best. The developed formula enabled to produce four variants of the fertilizer based on biochar, effective microorganisms, mycorrhizal fungi, Rhizobium bacteria and algae.

Depending on individual needs, the fertilizer can be used in the cultivation of vegetables, field or ornamental plants. Each of the afore-mentioned fertilizer variants have a soil conditioning effect and primarily improve the physicochemical properties of the soil and plants, which in consequence have positive results on the yield and quality of the crop. During the implementation, the composition of the fertilizer mixture was chosen, including the preparations containing microorganisms, algae or their extracts, as well as mycorrhizae for the studied plant species. Currently, pot and field tests are being carried out to determine the effectiveness of the produced fertilizers, including yield and phytosanitary properties.

The idea of the above-mentioned fertilizer production can be mainly seen in fertilizing, economic and environmental benefits. The economic benefits take into account the possibility of reducing costs on the purchase of mineral fertilizers. Satisfying part of the needs of plants by ingredients contained in the produced fertilizer is, on the other hand, an environmental benefit. Such results are due to the behavior of components, mainly nitrogen, and from phytosanitary activity, which in turn translates into savings on the purchase of chemicals related to plant protection. In addition to the innovative application of fertilizer by improvement of soil properties, measures will also be taken to determine the impact of the product on biological waste treatment processes, mainly in composting and methane fermentation.
The use of organic fertilizers in the fertilization process has basically two main purposes: the first is to provide organic matter to soil necessary for the formation of soil humus, the second, more as a complement, to supply nutrients. In both cases, regardless of the type of fertilizer used, they must be applied in a balanced fertilizer system. The main point is to take into account the nutritional needs of plants, supply the soil with digestible ingredients, mainly phosphorus and potassium, so as not to allow soil degradation in general. This is related to the use of this group of fertilizers not only in proper quantity, but also in good quality. What is more, they have a positive effect on the soil properties and structure as well as the water retention ability, being a good source of available nutrients for plants [Odlare et al., 2011].

\section{CONCLUSION}

The role of fertilizers is to provide nutrients for plants, as their properties determine the fertility of soils. Organic fertilizers are gaining popularity due to the fact that the problems of deficiency of not only nutrients in plants, but also organic matter, are more and more often noticed. Organic fertilizers are opening a way to solve both problems mentioned above, especially considering that their price is much lower than that of mineral fertilizers, and production can take place on almost every farm. Biochar is a product that has been known for many years, but now it is being rediscovered. The number of studies conducted all over the world clearly show its positive role in environmental protection, agriculture and waste management. Therefore, it is suggested to conduct further studies in this area, preferably in the direction of organic fertilizer production coming from agricultural and food waste.

\section{Acknowledgements}

This study was performed within the scope of the project: "Research on the Innovative Form of Organic Fertilisers" that was financed by the European Regional Development Fund under Regional Operational Programme - Priority Axis 1 - Lubuskie 2020 within the No. RPLB.01.01.00-08-0047/16-00. 


\section{REFERENCES}

1. Act of 10 July 2007 on fertilizers and fertilization

2. Arkhipchenko I.A., Salkinoja-Salonen M.S., Karyakina J.N., Tsitko I. 2005. Study of three fertilizers produced from farm waste. Applied Soil Ecology, 30, 126-132.

3. Beesley L., Moreno-Jimenez E., Gomez-Eyles J. L., Harris E., Robinson B., Sizmur T. 2011. A review of biochars' potential role in the remediation, revegetation and restoration of contaminated soils. Environmental Pollution, 159, 3269-3282.

4. Bot A. Benites J. 2005. The importance of soil organic matter - Key to drought-resistant soil and sustained food and production. FAO soils bulletin. ISBN 92-5-105366-9.

5. Brockmann D., Pradel M., Hélias A. 2018. Agricultural use of organic residues in life cycle assessment: Current practices and proposal for the computation of field emissions and of the nitrogen mineral fertilizer equivalent. Resources, Conservation and Recycling, 133, 50-62.

6. Cha J.S., Park S.H., Jung S-C., Ryu C., Jeon J-K., Shin M-C., Park Y-K. 2016. Production and utilization of biochar: A review. Journal of Industrial and Engineering Chemistry, 40, 1-15.

7. Czekała W., Malińska K., Cáceres R., Janczak D., Dach J., Lewicki A. 2016. Co-composting of poultry manure mixtures amended with biochar - The effect of biochar on temperature and C- $\mathrm{CO}_{2}$ emission. Bioresource Technology, 200, 921-927.

8. Czekała W. Concept of IN-OIL project based on bioconversion of by-products from food processing industry. 2017. Journal of Ecological Engineering, 18(5), 180-185.

9. Czekała W., Dach J., Dong R., Janczak D., Malińska K., Jóźwiakowski K., Smurzyńska A., Cieślik M. 2017. Composting potential of the solid fraction of digested pulp produced by a biogas plant. Biosystems Engineering, 160, 25-29.

10. Czekała W. 2018. Agricultural Biogas Plants as a Chance for the Development of the Agri-Food Sector. Journal of Ecological Engineering, 19(2), 179-183.

11. Dias B.O., Silva C.A., Higashikawa F.S., Roig A., Sanchez-Monedero M.A. 2010. Use of biochar as bulking agent for the composting of poulty manure: Effect on organic matter degradation and humification. Bioresource Technology, 101, 1239-1246.

12. Edwards J., Pittelkow C., Kent A., Yang W. 2018. Dynamic biochar effects on soil nitrous oxide emissions and underlying microbial processes during the maize growing season. Soil Biology and Biochemistry, 122, 81-90.

13. Ekielski A., Żelaziński T., Durczak K. 2017. The use of wavelet analysis to assess the degree of wear of working elements of food extruders. Eksploatacja i Niezawodność - Maintenance and Reliability, 19(4), 560-564.

14. Fageria N.K., Baligar V.C., Li Y.C. 2008. The Role of Nutrient Efficient Plants in Improving Crop Yields in the Twenty First Century. Journal of Plant Nutrition, 31(6), 1121-1157.

15. Flaig W. 1968. Einwirkung von organischen Bodenbestandteilen auf das Pflanzenwachstum. Landwirtsch. Forsch., XXI, 2, 103-127.

16. Gorlach E., Mazur T. 2002. Agricultural Chemistry (in Polish), Wydawnictwo Naukowe PWN, Warszawa.

17. Gwenzi W., Muzava M., Mapanda F., Tauro T.P. 2016. Comparative short-term effects of sewage sludge and its biochar on soil properties, maize growth and uptake of nutrients on a tropical clay soil in Zimbabwe. J. Integr. Agric., 15, 1395-1406.

18. Hasegawa H., Furukawa Y., Kimura S.D. 2005. On-farm assessment of organic amendments effects on nutrient status and nutrient use efficiency of organic rice fields in Northeastern Japan. Agriculture, Ecosystems \& Environment, 108, 350-362.

19. Jannoura R., Joergensen R.G., Bruns C. 2014. Organic fertilizer effects on growth, crop yield, and soil microbial biomass indices in sole and intercropped peas and oats under organic farming conditions. European Journal of Agronomy, 52, 259-270.

20. Keating B.A., Herrero M., Carberry P.S., Gardner J., Cole M.B. 2014. Food wedges: Framing the global food demand and supply challenge towards 2050. Global Food Security, 3, 125-132.

21. Ketonen M. 1992. Models of a Continuous Fertilizer Granulation Process - Control Design Application. IFAC Proceedings Volumes 25 (15) 139-144.

22. Kończak M., Oleszczuk P. 2018. Application of biochar to sewage sludge reduces toxicity and improve organisms growth in sewage sludge-amended soil in long term field experiment. Science of The Total Environment, 625, 8-15.

23. Körschens M. 2013. Humus und Klimaänderung. Internationalen Grünen Woche in Berlin am 25. Januar 2013, 1-13.

24. Koszel M., Lorencowicz E. 2015. Agricultural Use of Biogas Digestate as a Replacement Fertilizers. Agriculture and Agricultural Science Procedia 7, 119-124.

25. Lehmann J., Rillig M. C., Thies J., Masiello C. A., Hockaday W. C., Crowley D. 2011. Biochar effects on soil biota - A review. Soil Biology \& Biochemistry, 43, 1812-1836.

26. Li C., Ma S., Shao Y., Zhang L., 2018. Effects of long-term organic fertilization on soil microbiologic characteristics, yield and sustainable production of winter wheat. Journal of Integrative Agriculture, 17(1), 210-219. 
27. Luz F.C., Cordiner S., Manni A., Mulone V., Rocco V. 2018, Biochar characteristics and early applications in anaerobic digestion-a review. Journal of Environmental Chemical Engineering, 6, 2892-2909.

28. Malińska K. 2012. Biochar - a response to current environmental issues (in polish). Inżynieria i Ochrona środowiska, 4, 387-403.

29. Malińska K., Zabochnicka-Świątek M., Dach J. 2014. Effects of biochar amendment on ammonia emission during composting of sewage sludge. Ecological Engineering, 71, 474-478.

30. Malińska K. 2015. Legal and Quality Aspects of Requirements for Biochar (in polish). Inżynieria i Ochrona Środowiska, 18(3), 359-371.

31. Malińska K., Dach J. 2015. Biochar as a supplementary material for biogas production. Ecological Engineering, 41, 117-124.

32. Maiti S., Dey S., Purakayastha S., Gosh B. 2005. Physical and thermochemical characterization of rice husk char as a potential biomass energy source. Bioresource Technology, 97, 2065-2070.

33. Mohan D., Pittman Jr. C. U., Arsenic removal from water/wastewater using adsorbents - a critical review. Journal of Hazardous Materials, 142, 1-53.

34. Mumme J., Srocke F., Heeg K., Werner M. 2014. Use of biochars in anaerobic digestion. Bioresource Technology, 164, 189-197.

35. Odlare M., Arthurson V., Pell M., Svensson K., Nehrenheim E., Abubaker J. 2011. Land application of organic waste - Effects on the soil ecosystem. Applied Energy, 88(6), 2210-2218.

36. Oleszczuk P., Rycaj M., Lehmann J., Cornelissen G. 2012. Influence of activated carbon and biochar on phytotoxicity of air-dried sewage sludges to Lepidium sativum. Ecotoxicol. Environ. Saf. 80, 321-326.

37. Ouni Y., Ghnaya T., Montemurro F., Abdelly Ch., Lakhdar A. 2014. The role of humic substances in mitigating the harmful effects of soil salinity and improve plant productivity. International Journal of Plant Production, 8 (3), 353-374.
38. Saifullah, Dahlawi S., Naeem A., Rengel Z., Naidu R. 2018. Biochar application for the remediation of salt-affected soils: Challenges and opportunities. Science of The Total Environment, 625, 320-335.

39. Steinbeiss et al., 2009 Effects of biochar amendment on soil carbon balance and soul microbal activity. Soil Biology \& Biochemistry, 41, 1301-1310.

40. Tóth G., Montanarella L., Rusco E., 2008. Updated Map of Salt Affected Soils in the European Union, Threats to Soil Quality in Europe, Office for the Official Publications of the European Communities, 61-74.

41. Yu X., Mu Ch., Gu Ch., Liu C., Liu X. 2011. Impact of woodchip biochar amendment on the sorption and dissipation of pesticide acetamiprid in agricultural soils. Chemosphere, 85, 1284-1289.

42. Verheijen, F.G.A., Jeffery S., Bastos A.C., ver der Velde M., Diafas I. 2009, Biochar application to soils-a critical scientific review of effects on soil properties, processes and functions. In: EUR 24099 EN. Office for the Official Publications of the European Communities, Luxembourg.

43. Vikrant K., Kim K., Ok Y.S., Tsang D.C.W., Tsang Y.F., Giri B.S., Singh R.S. 2018, Engineered/designer biochar for the removal of phosphate in water and wastewater. Science of the Total Environment, 616-917, 1242-1260.

44. Weber K., Quciker P. 2018. Properties of biochar. Fuel, 217, 240-261.

45. Wojcieszak D., Przybył J., Lewicki A., Ludwiczak A., Przybylak A., Boniecki P., Koszela K., Zaborowicz M., Przybył K., Witaszek K. 2015. Use of neural image analysis methods in the process of determine the dry matter content in the compost. Proc. of SPIE Vol. 9631 963118-1.

46. Zhang D., Pan G., Wu G., Kibue G.W., Li L., Zhang X., Zheng J., Zheng J., Cheng K., Joseph S., Liu X. 2016. Biochar helps enhance maize productivity and reduce greenhouse gas emissions under balanced fertilization in a rainfed low fertility inceptisol. Chemosphere, 142, 106-113. 